\title{
Classical dry ashing of biological and agricultural materials. Part II. Losses of analytes due to their retention in an insoluble residue*
}

\author{
P. Mader**, J. Száková and D. Miholová \\ Department of Chemistry, Faculty of Agronomy, Czech University of Agriculture, \\ CZ-16521 Prague 6-Suchdol, Czech Republic
}

\begin{abstract}
Retention of selected analytes $(\mathrm{Cd}, \mathrm{Cr}, \mathrm{Cu}, \mathrm{Mn}, \mathrm{Pb}, \mathrm{Zn})$ in solid residue which remains undissolved in $1.5 \% \mathrm{HNO}_{3}$ used as a leaching medium after classical dry ashing of ten materials (alfalfa leaves, NIST SRM 1569 Brewer's Yeast, blood meal, meat-bone meal, feather-bone meal, silage residue, litter, pond sediment, coal waste, IRM NSC-21 Industrial Compost Vitahum) was studied. The elements remaining in the residue were determined mainly by AAS after dissolution of this residue in the mixture of $\mathrm{HF}+\mathrm{HNO}_{3}$. In several instances, pressurized wet digestion, alkaline fusion, stripping voltammetry and instrumental neutron activation were also applied. Increasing concentration of mineral acid in leaching medium which does not contain HF, plus increasing final volume of the solution, suppresses significantly this type of analyte losses in the majority of matrices tested. However, for industrial compost and standard reference material NIST 1569 Brewer's Yeast, application of an HF step is necessary for quantitative release of the analytes (in particular chromium) into solution.
\end{abstract}

Key words. Biological and agricultural materials - dry ashing - trace element analysis - analyte losses.

\section{Introduction}

When well performed, the classical dry ashing procedure leads to complete removal of the organic matrix and to accurate analytical results for a number of determined elements [1]. In the case of soft animal tissues, the ultimate decomposition product - ash - is dissolved completely in the used leaching medium $\left(1.5 \% \mathrm{HNO}_{3}\right)$. Ash of other materials studied is dissolved only partly, leaving small solid insoluble residue. In this communication we follow chemical composition of this residue and the risk (see e.g. [2,3]) of possible analyte losses due to their partial retention in the residue. Ten materials of biological origin or with significant content of organic components have been tested: Alfalfa leaves, NIST SRM 1569 Brewer's Yeast, blood meal, meat-bone meal, feather-bone meal, silage residue, litter, pond sediment, coal waste, IRM NSC-21 Compost Vitahum. With the exception of animal meals, initial procedure of classical dry ashing was the same as that developed by us for soft animal tissues (see Appendix in reference [4]). It was anticipated that this procedure will have to be modified in particular steps in order to provide accurate analytical results also for other types of biological and agricultural matrices.

\section{Material and methods}

\section{Alfalfa leaves}

Two materials denoted as PDS-84 and PDS-85 were from the crops harvested in 1984 and 1985. Both materials were dry ashed mostly according to the SOP-1 described in [4]; the only exception from this procedure being in that the ultrasonic bath was not yet introduced as a support of ash leaching. Aliquot of the ash was dried and weighed before leaching, and subsequently analyzed by X-ray structural analysis. Another aliquot was leached in $1.5 \% \mathrm{HNO}_{3}$. About two-thirds of the original ash got dissolved into this leaching medium, leaving small insoluble silicious residue. The latter residue was dried again, weighed and also analyzed by $\mathrm{X}$ -

\footnotetext{
* The first part appeared in Analusis 1997, 25, 175-183.

** Cor respondence and reprints.

Received No vember 19, 1997; revised February 11, 1998; accepted February 18, 1998.
} 
ray structural analysis. Its content of selected elements $(\mathrm{Cd}$, $\mathrm{Cu}, \mathrm{Co}, \mathrm{Ni}, \mathrm{Pb}, \mathrm{Zn}$ ) was determined by instrumental neutron activation analysis (INAA) and/or atomic absorption spectrometry (AAS); in the case of $\mathrm{Cd}, \mathrm{Cu}$ and $\mathrm{Pb}$ also by differential pulse anodic stripping voltammetry (DPASV). In the latter two cases, silicious residue had to be first dissolved in the mixture of conc. $\mathrm{HNO}_{3}+\mathrm{HF}(2+1)$ in $100 \mathrm{~mL}$ Teflon beakers. After removal of silicon, acids and water by slow evaporation on Teflon-covered hot plate at $150{ }^{\circ} \mathrm{C}$, the solid residue was dissolved in $0.1-\mathrm{M} \mathrm{HNO}_{3}$. Instrumentation included a flame atomic absorption spectrometer Varian SpectrAA-40 (Australia), a Perkin-Elmer 4000 atomic absorption spectrometer (USA) with a HGA-500 graphite furnace (ET-AAS), and polarographic analyser PA-3 with SMDE-1 static mercury drop electrode, Laboratorní prístroje, Czech Republic (DPASV). For X-ray structural analysis of the plant ash and of its silicious residue the difractometer DRON-2, Cu-radiation and C-filter were used. For the evaluation we used American conversion table ICPDS; corresponding indexes are given in parentheses behind the formulas presented in the part Results. Arc atomic emission spectrography was performed using a spectrograph PGS-2 (Zeiss, Germany).

\section{NBS SRM 1569 Brewer's Yeast}

Solid residues from 13 individual digests obtained by dry ashing of this reference material according to SOP-1 were combined into one integrated sample and treated by the mixture of $\mathrm{HF}$ and $\mathrm{HNO}_{3}$ as described above for alfalfa leaves. $\mathrm{Cr}$ content in the $0.1-\mathrm{M} \mathrm{HNO}_{3}$ solution was determined by flame atomic absorption spectrometry (FAAS) with $\mathrm{N}_{2} \mathrm{O}-$ acetylene flame.

\section{Animal meals}

Three types of animal meals used (meat-bone, feather-bone and blood meal) were described elsewhere [5]. SOP-1 has been modified in the step of ash leaching: Instead of $1.5 \%$ $\mathrm{HNO}_{3}$, the ash was leached by $10 \% \mathrm{HNO}_{3}$ Solid residue still remaining was dissolved with the mixture of $\mathrm{HF}+\mathrm{HNO}_{3}$ $(1+2)$ and contents of $\mathrm{Pb}, \mathrm{Cd}$ and $\mathrm{Cr}$ (final solutions in $1.5 \% \mathrm{HNO}_{3}$ ) were determined by FAAS (air-acetylene for $\mathrm{Cd}$ and $\mathrm{Pb}, \mathrm{N}_{2} \mathrm{O}$-acetylene for $\mathrm{Cr}$ ).

\section{Components of industrial compost}

Eight samples of four different sorts of components of industrial composts commonly used in the Czech Republic (coal waste, pond sediment, silage residue, litter) were analyzed for their contents of $\mathrm{Pb}, \mathrm{Cd}$ and $\mathrm{Cr}$ by FAAS after the SOP-1 dry ashing. The insoluble fractions of the ash were washed by deionized water, quantitatively transferred to Teflon beakers and mixture of $\mathrm{HF}+\mathrm{HNO}_{3}(1+2)$ was added $(45 \mathrm{~mL}$ per $1 \mathrm{~g}$ of the sample). Since after this treatment still relatively considerable part of residue remained insoluble (see Fig. 1), the $\mathrm{HF}+\mathrm{HNO}_{3}$ treatment was repeated. The part of analytes which got dissolved in the mixture of $\mathrm{HF}+\mathrm{HNO}_{3}$ was determined by FAAS. The solid residue which remained insoluble after this second treatment was dried, weighed and subsequently decomposed by either aggressive wet decomposition or by alkaline fusion described below. a) insoluble in $1.5 \% \mathrm{HNO}_{3}$

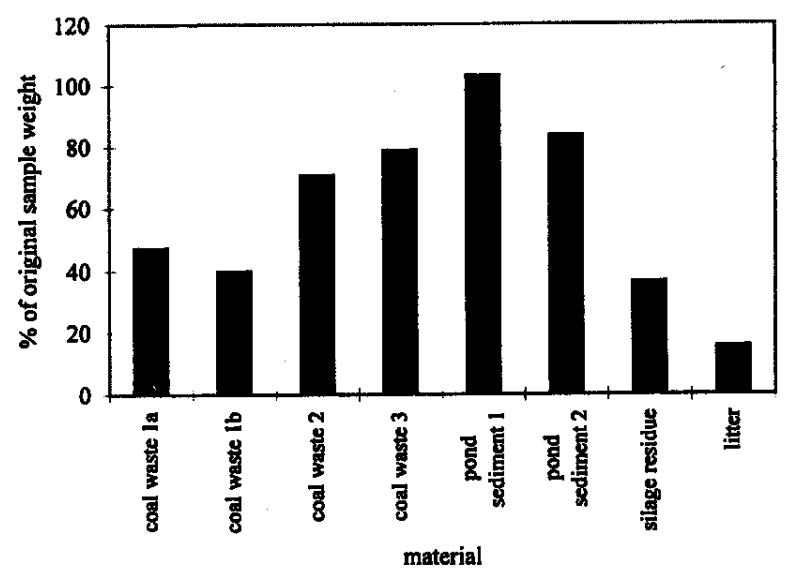

b) insoluble in $\mathrm{HF}+\mathrm{HNO}_{3}$

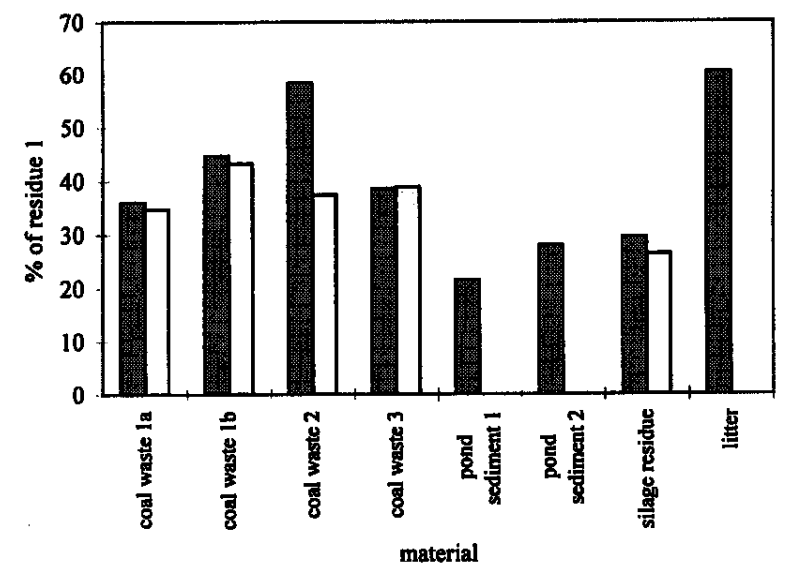

Fig. 1. Ratio of insoluble residues after dry ashing of selected components of compost; residue 1: insoluble in $1.5 \% \mathrm{HNO}_{3}$, residue 2: after $\mathrm{HF}+\mathrm{HNO}_{3}$ attack of residue 1, residue 3: after $\mathrm{HF}+\mathrm{HNO}_{3}$ attack of residue 2 . Residue 3 for pond sediments and litter not determined. $\square$ residue $1, \square$ residue $2, \square$ residue 3 .

Wet decomposition: About $0.2 \mathrm{~g}$ of sample was exactly weighed in a platinum crucible and calcified on the flame. The samples were then digested by a mixture of conc. HF and conc. $\mathrm{H}_{2} \mathrm{SO}_{4}$ at $80{ }^{\circ} \mathrm{C}$ overnight. Since the sample mass was not affected we conclude that all silicon present was completely removed already by previous treatment with HF $+\mathrm{HNO}_{3}$. The samples were decomposed by pressurized wet digestion in conc. $\mathrm{HCl}$ at $200{ }^{\circ} \mathrm{C}$ for $20 \mathrm{~h}$. In the case of the pond sediment, a fine black material remained after this treatment; it has been removed by filtration. Solutions were filled up to $100 \mathrm{~mL}$ by distilled water in polyethylene volumetric flasks. Contents of $\mathrm{Ca}, \mathrm{Mn}, \mathrm{Fe}$ and $\mathrm{Mg}$ were determined by FAAS, while those of $\mathrm{Na}$ and $\mathrm{K}$ by flame atomic emission spectrometry (FAES). $0.1 \% \mathrm{La}^{3+}$ and $0.3 \% \mathrm{Cs}^{+}$ solutions were added as spectrochemical buffers. The content of $\mathrm{P}$ was determined spectrophotometrically by measurement of yellow color of phosphomolybdate complex in presence of $\mathrm{HClO}_{4}$ which was added after the evaporation of $\mathrm{HCl}$. 
Alkaline fusion: Exactly about $0.2 \mathrm{~g}$ of sample was fused in platinum crucible with a mixture of $\mathrm{Na}_{2} \mathrm{CO}_{3}$ and $\mathrm{KNO}_{3}$ at $750{ }^{\circ} \mathrm{C}$. After this treatment, the sample was quantitatively transferred by $40 \mathrm{~mL}$ of diluted $\mathrm{HCl}(1+1)$ into a 250 $\mathrm{mL}$ volumetric flask and filled up to mark by distilled water. Content of Ti in this solution was determined spectrophotometrically with TIRON in acetate buffer in presence of thioglycolic acid; the sum of $\mathrm{Fe}+\mathrm{Al}+\mathrm{Ti}$ was determined complexometrically in urotropine - buffered solution by retitration of superfluous CYDTA (cyclohexanediamine tetraacetic acid) by $0.05-\mathrm{M} \mathrm{Zn}$ solution with xylene orange.

In one sample of coal waste, macro- and microelements were determined also by INAA.

\section{IRM NSC-21 Compost Vitahum}

Two experiments were carried out in order to determine optimal decomposition procedure for this material:

Experiment I: Material was ashed according to the SOP1 and five variations of ash leaching were applied (1-5, Tab. I). In each variant, eight $1 \mathrm{~g}$ portions of sample were decomposed and $\mathrm{Cd}, \mathrm{Cu}, \mathrm{Cr}, \mathrm{Mn}, \mathrm{Pb}$ and $\mathrm{Zn}$ were determined in the leachate by FAAS (acetylene-air). Solid residues of three digests from each variant were collected and treated by the mixture of $\mathrm{HF}$ and $\mathrm{HNO}_{3}$ similarly as in the above described case of industrial compost components and contents of $\mathrm{Cd}, \mathrm{Cu}, \mathrm{Cr}, \mathrm{Mn}, \mathrm{Pb}$ and $\mathrm{Zn}$ determined in resulting solutions.

Experiment II: Dry ashing according to SOP-1 was compared with dry ashing completed by decomposition of sili- cious residue in HF, and with wet digestion. Variants A-D are specified in table I.

All the solutions were measured for contents of $\mathrm{Pb}, \mathrm{Cd}$ and $\mathrm{Cr}$ by FAAS (acetylene-air). For $\mathrm{Cr}$, acetylene- $\mathrm{N}_{2} \mathrm{O}$ flame was used.

Statistical evaluation of the results was carried out with the $t$-test at the significance level $\alpha=0.05$.

\section{Results}

\section{Alfalfa leaves PDS-84}

\section{Analysis of the silicious fraction of the ash}

INAA analysis has shown (Table II) that the main matrix elements are $\mathrm{Ca}(11-12 \%), \mathrm{S}(10 \%)$ and $\mathrm{Si}(8-10 \%)$, followed by $\mathrm{K}(4 \%), \mathrm{Fe}(0.6 \%)$, and $\mathrm{Na}(0.3 \%)$. Neither phosphorus nor oxygen were determined. If we express $\mathrm{S}$ as $\mathrm{SO}_{4}$ and the other matrix elements as oxides $\left(\mathrm{Fe}\right.$ as $\left.\mathrm{Fe}_{2} \mathrm{O}_{3}\right)$, we get $32.9 \%$ for oxygen in the residue, and the sum of the elements $\mathrm{Ca}, \mathrm{S}, \mathrm{Si}, \mathrm{K}, \mathrm{Fe}, \mathrm{Na}$ and $\mathrm{O}$ represents $68 \%$ of the residue mass. It can be assumed that it also contains phosphorus, which in the form of phosphate or polyphosphates is probably responsible for most of the remaining $32 \%$ of the residue mass.

The INAA analysis further revealed that the residue contains, even though in trace amounts, a number of other elements. Of those that we determined in the supernatant, $\mathrm{Cd}, \mathrm{Co}$, and $\mathrm{Zn}$ have been found by INAA also in the residue. The determination limit of Cd by INAA is very high

Table I. Individual variants of experiments with IRM NSC-21. Experiment I: modifications of ash leaching step in dry ashing according to SOP-1; Experiment II: dry and wet ashing, also in combination.

Experiment I:

Variant Ash leaching Additional operations

$15 \mathrm{~mL}$ of $1.5 \% \mathrm{HNO}_{3}$

$25 \mathrm{~mL}$ of $\mathrm{HNO}_{3}$ conc., filled up to $15 \mathrm{~mL}$ by $1.5 \% \mathrm{HNO}_{3}$

$35 \mathrm{~mL}$ of $\mathrm{HNO}_{3}$ conc.

$44 \mathrm{~mL}$ of $\mathrm{HNO}_{3}$ conc. $+1 \mathrm{~mL}$ of $\mathrm{H}_{2} \mathrm{SO}_{4}$ conc.,

filled up to $15 \mathrm{~mL}$ by $1.5 \% \mathrm{HNO}_{3}$

$54 \mathrm{~mL}$ of $\mathrm{HNO}_{3}$ conc. $+1 \mathrm{~mL}$ of $\mathrm{H}_{2} \mathrm{SO}_{4}$

Additional operations

$-$

Evaporated on hot plate $\left(160^{\circ} \mathrm{C}\right)$, dissolved in ultrasonic bath in $15 \mathrm{~mL}$ of $1.5 \% \mathrm{HNO}_{3}$

evaporated on hot plate $\left(320^{\circ} \mathrm{C}\right)$, dissolved in ultrasonic bath in $15 \mathrm{~mL}$ of $1.5 \% \mathrm{HNO}_{3}$

Experiment II:

\begin{tabular}{|c|c|c|c|}
\hline Variant & Type of ashing & Ashing operations & Final dissolution of the digest \\
\hline A & dry ashing & see SOP-1 [4] & see variant 2 of experiment I \\
\hline B & combined wet and dry ashing & $\begin{array}{l}\text { wet ashing in } \mathrm{HF}+\mathrm{HNO}_{3} \text { mixture } \\
\text { at } 150{ }^{\circ} \mathrm{C} \text { followed by dry ashing } \\
\text { according to variant } \mathrm{A}\end{array}$ & according to variant $\mathrm{A}$ \\
\hline $\mathrm{C}$ & dry ashing & $\begin{array}{l}\text { sample mass } 20 \% \text { less as compared } \\
\text { to A, all remaining steps as in A }\end{array}$ & $50 \mathrm{~mL}$ of $1.5 \% \mathrm{HNO}_{3}$, filtration of the ash \\
\hline $\mathrm{D}$ & wet ashing & $\begin{array}{l}5 \mathrm{~mL} \mathrm{HNO}_{3}+5 \mathrm{~mL} \mathrm{H}_{2} \mathrm{O}_{2}+ \\
1 \mathrm{~mL} \mathrm{H}_{2} \mathrm{SO}_{4} \text { under reflux at } 210{ }^{\circ} \mathrm{C}\end{array}$ & $\begin{array}{l}100 \mathrm{~mL} \text { of diluted } \mathrm{HCl} \\
\text { (final concentration of } \mathrm{HCl} 1-\mathrm{M} \text { ) }\end{array}$ \\
\hline
\end{tabular}


Table II. Results for INAA elemental analysis of silicious residue after dry ashing of alfalfa leaves PDS-84. Except $\mathrm{Ca}, \mathrm{K}, \mathrm{S}$ and $\mathrm{Si}$, contents are given in $\mathrm{mg} \mathrm{kg}^{-1}$.

\begin{tabular}{lccccc}
\hline Element & Content & Element & Content & Element & Content \\
\hline $\mathrm{Al}$ & 7310 & $\mathrm{Eu}$ & 0.25 & $\mathrm{Sc}$ & 1.97 \\
$\mathrm{As}$ & 8.37 & $\mathrm{Fe}$ & 4670 & $\mathrm{Si}$ & $7.98 \%$ \\
$\mathrm{Au}$ & 0.0065 & $\mathrm{Hf}$ & 2.75 & $\mathrm{Sm}$ & 1.37 \\
$\mathrm{Ba}$ & 2200 & $\mathrm{~K}$ & $3.81 \%$ & $\mathrm{Sr}$ & 362 \\
$\mathrm{Ca}$ & $12.0 \%$ & $\mathrm{La}$ & 12.0 & $\mathrm{Ta}$ & 0.39 \\
$\mathrm{Cd}$ & $<2$ & $\mathrm{Mn}$ & 101 & $\mathrm{Ti}$ & 1460 \\
$\mathrm{Ce}$ & 15.4 & $\mathrm{Na}$ & 2450 & $\mathrm{Th}$ & 2.38 \\
$\mathrm{Cr}$ & 17.4 & $\mathrm{Rb}$ & 27.0 & $\mathrm{~V}$ & 10.6 \\
$\mathrm{Cs}$ & 0.76 & $\mathrm{~S}$ & $9.57 \%$ & $\mathrm{~W}$ & 1.57 \\
$\mathrm{Co}$ & 1.00 & $\mathrm{Sb}$ & 1.05 & $\mathrm{Zn}$ & 39.8 \\
\hline
\end{tabular}

( $2 \mathrm{mg} \mathrm{kg}^{-1}$ ) and thus the analytical result for the $\mathrm{Cd}$ content in the residue, i.e. $<2 \mathrm{mg} \mathrm{kg}^{-1}$, is not of use for estimation of retention of cadmium in the residue. For cobalt and zinc we found values of $1 \mathrm{mg} \mathrm{kg}^{-1}$ and $39.8 \mathrm{mg} \mathrm{kg}^{-1}$, respectively. Taking into account the original weight of the sample PDS-84, these contributions represent $40 \mu \mathrm{g} \mathrm{kg}^{-1}$ for Co, and $1.57 \mathrm{mg} \mathrm{kg}^{-1}$ for $\mathrm{Zn}$. If we compare these values with those found in the supernatant and relate them to the original weight of sample PDS-84, it follows (Tab. III) that the fraction of the total heavy metal content retained in the insoluble residue represents $17 \%$ for $\mathrm{Co}$, and $4.9 \%$ for $\mathrm{Zn}$.

\section{Alfalfa leaves IRM PDS-85}

\section{Analysis of ash}

$\mathrm{X}$-ray structural analysis of the ash has revealed two main crystalline components, i.e. $\left(\mathrm{Ca}_{0.04} \mathrm{Mg}_{0.45} \mathrm{Fe}_{0.48}\right) \mathrm{SiO}_{3}$ (13-421) pigeonite and $\mathrm{KCl}$ (4-587) sylvine. $\mathrm{CaCO}_{3}$ calcite and $\mathrm{SiO}_{2}$ quartz form further constituents. The used method is able to detect only crystalline components which are present in amounts exceeding $5-10 \%$. Chemical analysis of the ash (h)as shown that it contains $0.69 \%$ of $\mathrm{NO}_{3}^{-}$. Weight loss due to incineration of the ash at $1000{ }^{\circ} \mathrm{C}$ to the constant weight represents $35.0 \%$. Arc spectrographic emission analysis revealed lines of $\mathrm{A} 1, \mathrm{Ba}, \mathrm{Bi}, \mathrm{Ca}, \mathrm{Fe}, \mathrm{Mg}, \mathrm{Mn}, \mathrm{Ni}, \mathrm{P}, \mathrm{Pb}$, and $\mathrm{Sn}$. Emission lines of $\mathrm{As}, \mathrm{Co}, \mathrm{Sb}$ and $\mathrm{Zn}$ were not detected.

\section{Analysis of the silicious fraction of the ash}

$\mathrm{X}$-ray structural analysis showed that the major crystalline component of the insoluble residue is $\mathrm{SiO}_{2}$. In addition, $\mathrm{Ca}_{2}\left(\mathrm{SO}_{4}\right)_{2} \cdot \mathrm{H}_{2} \mathrm{O}$ (24-1068) bassenite (higher-temperature modification), $\mathrm{KNO}_{3}, \mathrm{CaCO}_{3}$ calcite, and $\mathrm{CaSO}_{4}$ anhydrite were also found in decreasing amounts. After the dissolution of the residue in the $\mathrm{HNO}_{3}+\mathrm{HF}$ mixture we determined $\mathrm{Cd}$ and $\mathrm{Pb}$ by DPASV. The Cd content was in all cases below the detection limit ( $1 \mu \mathrm{g} \mathrm{kg}{ }^{-1}$ of the residue); the $\mathrm{Cd}$ found in the supernatant represented after recalculation to the original weight the value of $0.117 \mathrm{mg} \mathrm{kg}^{-1} \mathrm{Cd}$ in PDS-85. Hence, after recalculation to the original material, the losses of $\mathrm{Cd}$ due to its retention in the sediment amount to less than $0.2 \%$. On the other hand, the $\mathrm{Pb}$ content varies significantly and the contribution of the residue makes 0.7 to $11.3 \%$ of the total $\mathrm{Pb}$ content in this material
( $\left.2.08 \mathrm{mg} \mathrm{kg}^{-1} \mathrm{~Pb}\right)$. The table III summarizes the contents of all elements both in the supernatant and in the sediment and for both PDS-84 and PDS-85.

\section{NBS SRM 1569 Brewer's Yeast}

After classical dry ashing according to SOP-1, only $1.35 \mathrm{mg} \mathrm{kg}^{-1} \mathrm{Cr}$, i.e. $65 \%$ of the certified value, was found. Another $0.8 \mathrm{mg} \mathrm{kg}^{-1} \mathrm{Cr}$ was found after dissolution of solid residue by the mixture of $\mathrm{HF}+\mathrm{HNO}_{3}$. The sum of these two values, i.e. $2.15 \mathrm{mg} \mathrm{kg}^{-1} \mathrm{Cr}$, agrees well with the certified value $2.12 \mathrm{mg} \mathrm{kg}^{-1} \mathrm{Cr}$.

\section{Animal meals}

In this case, the ash was leached by $10 \% \mathrm{HNO}_{3}$. After the subsequent treatment of the insoluble residue by the mixture of $\mathrm{HF}+\mathrm{HNO}_{3}$, only $40-60 \%$ of this residue got dissolved. Obviously the dominant part of this residue is not a silicate material. In the dissolved part of the residue, only 1.0 $-6.0 \%$ of total $\mathrm{Cd}, 1.5-4.7 \% \mathrm{~Pb}$ and $0.9-4.3 \% \mathrm{Cr}$ were found. In addition, ash leaching into larger volume of $\mathrm{HNO}_{3}$ can lead to better dissolution of matrix elements contained in the ash.

\section{Components of industrial compost}

Contents of $\mathrm{Pb}, \mathrm{Cd}$ and $\mathrm{Cr}$ in a fraction of analytes dissolved in the mixture of $\mathrm{HF}+\mathrm{HNO}_{3}$ are summarized in figure 2. Remaining part of lead, chromium and in a lower extent of cadmium in the solid residue after dissolving of the ash in $1.5 \% \mathrm{HNO}_{3}$ is evident. There are great differences among different materials and different samples collected on the same place, as well. However, retained analytes could be bound either inside the silicate residue or on its surface. More aggressive dissolution procedure recommended for chromium in [6] (add $5 \mathrm{~mL}$ of $\mathrm{HNO}_{3}$ conc., let stand for 1 hour and then dissolve the sample in diluted $\mathrm{HNO}_{3}$ using an ultrasonic bath) has indeed led to better release of elements from the insoluble residue. In our internal reference material SLUDGE B containing $450 \mathrm{mg} \mathrm{kg}^{-1} \mathrm{~Pb}$ we found only $184 \mathrm{mg} \mathrm{kg}^{-1} \mathrm{~Pb}$ after classical dry ashing according to SOP1 but $420 \mathrm{mg} \mathrm{kg}^{-1} \mathrm{~Pb}$ using more aggressive dissolution recommended in [6].

Multielement INAA analysis of coal waste sample (unfortunately without important matrix elements S, Si and P) suggests possible problems caused by very complex matrix of this type of sample (Tab. IV).

Macroelement composition of coal waste and pond sediment solid residues from dry ashing after repeated treatment by the mixture of $\mathrm{HF}+\mathrm{HNO}_{3}$ yielded the following results: for coal waste $\mathrm{Al}_{2} \mathrm{O}_{3} 22.9 \%, \mathrm{Fe}_{2} \mathrm{O}_{3} 11.3 \%, \mathrm{CaO} 0.34 \%, \mathrm{MgO}$ $0.79 \%, \mathrm{Na}_{2} \mathrm{O} 0.49 \%, \mathrm{~K}_{2} \mathrm{O} 1.08 \%, \mathrm{TiO}_{2} 0.96 \%, \mathrm{MnO} 0.04 \%$, $\mathrm{P}_{2} \mathrm{O}_{5} 0.60 \%$, loss after evaporation with $\mathrm{HF}+\mathrm{H}_{2} \mathrm{SO}_{4} 60.5 \%$; total 98.9\%: for pond sediment $\mathrm{Al}_{2} \mathrm{O}_{3} 27.5 \%, \mathrm{Fe}_{2} \mathrm{O}_{3} 5.41 \%$, $\mathrm{CaO} 2.98 \%, \mathrm{MgO} 1.99 \%, \mathrm{Na}_{2} \mathrm{O} 1.76 \%, \mathrm{~K}_{2} \mathrm{O} 6.75 \%, \mathrm{TiO}_{2}$ $1.92 \%, \mathrm{MnO} 0.07 \%, \mathrm{P}_{2} \mathrm{O}_{5} 0.47 \%$, loss after evaporation with $\mathrm{HF}+\mathrm{H}_{2} \mathrm{SO}_{4} 39.7 \%$; total $88.5 \%$. The complete removal of silicates by this procedure as well as great differences between individual samples studied are evident in this case.

\section{IRM NSC-21 Compost Vitahum}

Both consensus and information values of element contents in IRM NSC-21 [7] for the elements determined in this 

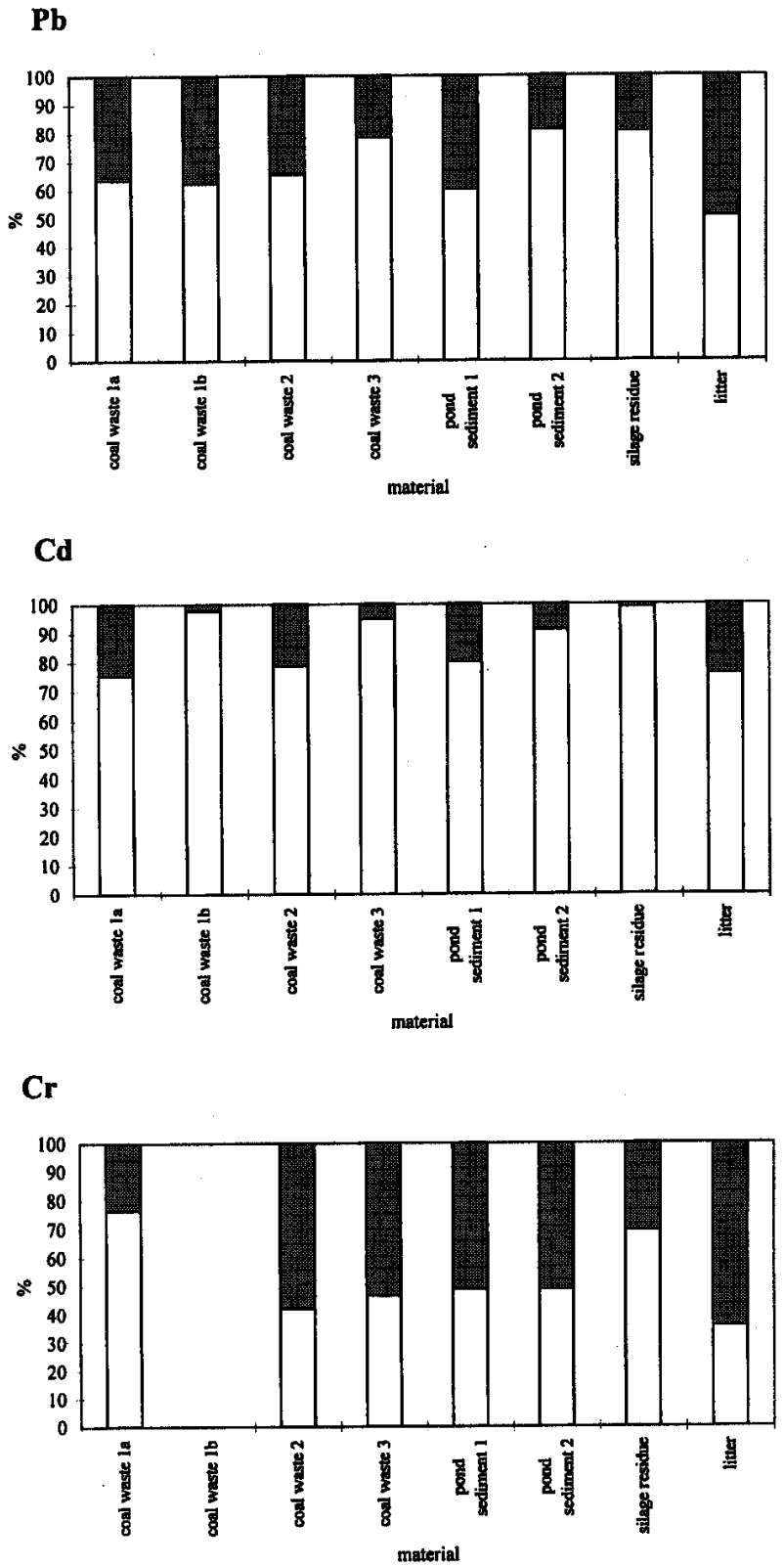

Fig. 2. Components of compost; the contents of $\mathrm{Pb}, \mathrm{Cd}$ and $\mathrm{Cr}$ in a fraction of ash which got dissolved in $1.5 \% \mathrm{HNO}_{3}$ and remaining solid residue. $100 \%$ = sum of both parts, $\mathrm{Cr}$ in coal waste $1 \mathrm{~b}$ not determined. $\square$ residue, solution.
Table IV. Results for INAA elemental analysis of coal waste sample. Except $\mathrm{Fe}$ and $\mathrm{K}$, results are given in $\mathrm{mg} \mathrm{kg}^{-1}$.

\begin{tabular}{|c|c|c|c|}
\hline Element & mean & $\begin{array}{l}\text { standard } \\
\text { deviation }\end{array}$ & $\begin{array}{c}\text { Relative } \\
\text { standard } \\
\text { deviation }(\%)\end{array}$ \\
\hline $\mathrm{Ag}$ & $<1.2$ & - & - \\
\hline As & 8.2 & 0.30 & 3.7 \\
\hline $\mathrm{Br}$ & 7.1 & 0.17 & 2.4 \\
\hline $\mathrm{Cd}$ & $<5$ & - & - \\
\hline $\mathrm{Ce}$ & 67.0 & 4.3 & 6.4 \\
\hline Co & 10.7 & 0.22 & 2.1 \\
\hline $\mathrm{Cr}$ & 111 & 3.9 & 3.5 \\
\hline Cs & 7.9 & 0.24 & 3.0 \\
\hline $\mathrm{Eu}$ & 1.03 & 0.033 & 3.2 \\
\hline $\mathrm{Fe}, \%$ & 2.42 & 0.169 & 7.0 \\
\hline $\mathrm{Hf}$ & 2.6 & 0.26 & 10.0 \\
\hline $\mathrm{Hg}$ & $<0.7$ & - & - \\
\hline $\mathrm{K}, \%$ & 0.448 & 0.028 & 6.2 \\
\hline $\mathrm{La}$ & 32.0 & 0.47 & 1.5 \\
\hline $\mathrm{Lu}$ & 0.23 & 0.048 & 20.9 \\
\hline Mo & 4.0 & 0.5 & 12.5 \\
\hline $\mathrm{Na}$ & $<0.35$ & - & - \\
\hline $\mathrm{Rb}$ & 60.0 & 3.0 & 5.0 \\
\hline $\mathrm{Sb}$ & 2.5 & 0.95 & 38.0 \\
\hline $\mathrm{Sc}$ & 16.2 & 0.13 & 0.8 \\
\hline $\mathrm{Se}$ & 5.7 & 0.51 & 9.0 \\
\hline $\mathrm{Sr}$ & 4.9 & 0.22 & 4.5 \\
\hline $\mathrm{Te}$ & 1.54 & 0.091 & 5.9 \\
\hline $\mathrm{Tn}$ & 10.2 & 0.29 & 2.8 \\
\hline V & 2.8 & 0.26 & 8.9 \\
\hline $\mathrm{W}$ & 1.5 & 0.10 & 6.7 \\
\hline $\mathrm{Yb}$ & 1.5 & 0.10 & 6.7 \\
\hline $\mathrm{Zn}$ & 83.0 & 6.1 & 7.4 \\
\hline
\end{tabular}

study are as follows: consensus values $0.457 \pm 0.047 \mathrm{mg}$ $\mathrm{kg}^{-1} \mathrm{Cd}, 27.2 \pm 2.6 \mathrm{mg} \mathrm{kg}{ }^{-1} \mathrm{Cu}, 14.7 \pm 1.2 \mathrm{mg} \mathrm{kg}^{-1} \mathrm{~Pb}$, $123 \pm 5 \mathrm{mg} \mathrm{kg}^{-1} \mathrm{Zn}$, information values $446 \pm 82 \mathrm{mg} \mathrm{kg}^{-1} \mathrm{Mn}$, $55.7 \pm 7.7 \mathrm{mg} \mathrm{kg}^{-1} \mathrm{Cr}$. Results of methodological study in which different methods of decomposition of the sample were applied are summarized in figures 3-5.

Table III. Comparison of the content of metals (in $\mu \mathrm{g} \mathrm{kg}^{-1}$ of alfalfa leaves) determined in the supernatant (AAS, DPASV) and in the insoluble residue.

\begin{tabular}{|c|c|c|c|c|c|c|}
\hline Metal & supernatant & $\begin{array}{c}P D S-84 \\
\text { residue }\end{array}$ & $\%$ of total & supernatant & $\begin{array}{l}P D S-85 \\
\text { residue }\end{array}$ & $\%$ of total \\
\hline Co & 192 & $40^{\mathrm{a}}$ & 17 & 159 & - & - \\
\hline $\mathrm{Cd}$ & 99 & $<2000^{\mathrm{a}}$ & - & 129 & $<0.25^{\mathrm{b}}$ & $<0.2$ \\
\hline $\mathrm{Cu}$ & 7800 & - & - & 8180 & - & - \\
\hline $\mathrm{Ni}$ & 1430 & - & - & 1430 & - & - \\
\hline $\mathrm{Pb}$ & 919 & - & - & 1890-1990 & $15-240^{\mathrm{b}}$ & $0.7-11.3$ \\
\hline $\mathrm{Zn}$ & 30500 & $1570^{\mathrm{a}}$ & 4.9 & 30400 & - & - \\
\hline
\end{tabular}

a) determined by INAA

b) determined by DPASV after dissolution of the residue in $\mathrm{HNO}_{3}+\mathrm{HF}$. 
Cd

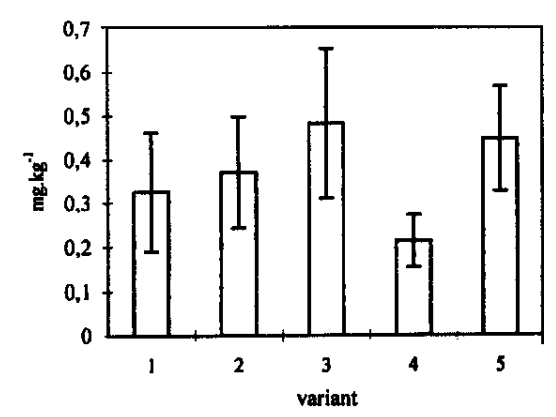

$\mathrm{Pb}$

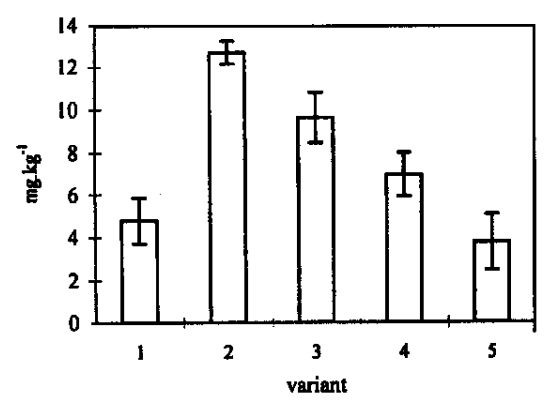

$\mathrm{Cu}$

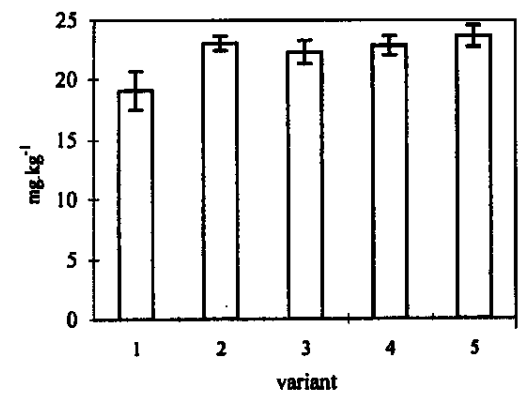

Mn

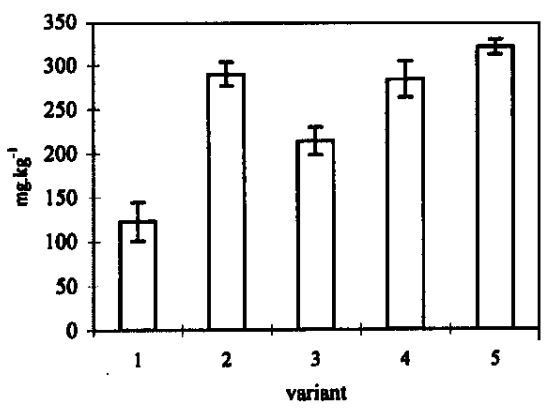

Cr

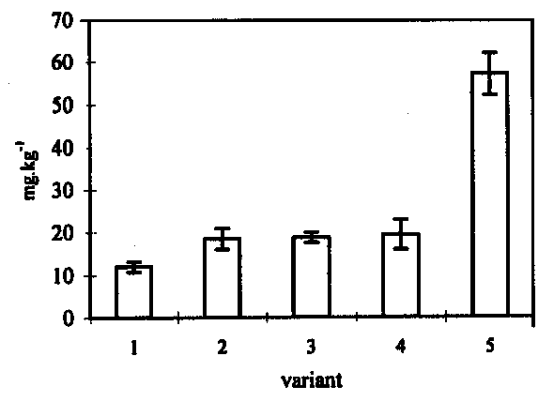

$\mathbf{Z n}$

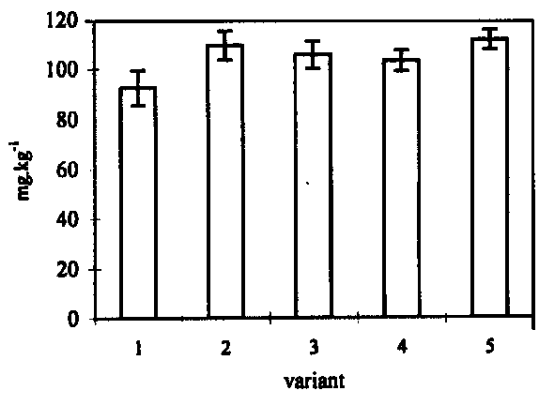

Fig. 3. Values for element contents in material NSC-21 $\left(\mathrm{mg} \mathrm{kg}^{-1}\right)$ obtained after ash leaching for individual variants of experiment I. Arithmetic means, $n=8$. Losses in insoluble residue were neglected.

\section{Experiment I}

The results for $\mathrm{Pb}, \mathrm{Cd}, \mathrm{Cu}, \mathrm{Cr}, \mathrm{Zn}$ and $\mathrm{Mn}$ after classical dry ashing (in dependence on individual variants mentioned in Tab. Ia) suggested insufficient release of all the elements studied in the case of variant 1 as compared to other variants. The application of more aggressive leaching techniques (i.e. $\mathrm{HNO}_{3}$ conc., $\mathrm{H}_{2} \mathrm{SO}_{4}$ conc.) led to comparable results for $\mathrm{Cu}$ and $\mathrm{Zn}$, while for $\mathrm{Pb}$ and $\mathrm{Mn}$, the evaporation of $\mathrm{HNO}_{3}$ used and the final dissolution of the sample in $1.5 \% \mathrm{HNO}_{3}$ resulted to repeated significant decrease of element contents in solutions.

In the case of lead, the application of $\mathrm{H}_{2} \mathrm{SO}_{4}$ as leaching agent caused serious losses of this element due probably to lead precipitation as $\mathrm{PbSO}_{4}$. The cadmium recovery was also affected by presence of $\mathrm{H}_{2} \mathrm{SO}_{4}$ (variant 4) in final sample solution. This may be attributed to an interference during AAS measurement, because the cadmium content in silicate part of solid residue from this variant was comparable with the variants 2, 3 and 5 (Fig. 4).

For variant 1 , the contents of $\mathrm{Cd}, \mathrm{Pb}, \mathrm{Cu}, \mathrm{Mn}$ and $\mathrm{Zn}$ were lower than the consensus and information values given above. When we added contributions of elements subsequently released from the solid residue, agreement with consensus values was reached for $\mathrm{Cd}$ and $\mathrm{Pb}$ (except variant 4), $\mathrm{Cu}$ and $\mathrm{Zn}$. For manganese, the result was still significantly lower then the information value. AAS measurement has indicated the influence of matrix components on manganese signal. The latter influence could be suppressed by 20 -fold dilution of the digest, which brought about $20-40 \%$ increase of the result. Value inside the $95 \%$ confidence interval could then be attained also for $\mathrm{Mn}$.

Chromium recoveries increased significantly when more agressive leaching techniques were used (compare variants $2-5)$. For variant 5 , the highest value $\left(61.5 \mathrm{mg} \mathrm{kg}^{-1}\right)$ corresponds well to information value $55.7 \mathrm{mg} \mathrm{kg}^{-1}$. However, 
cd

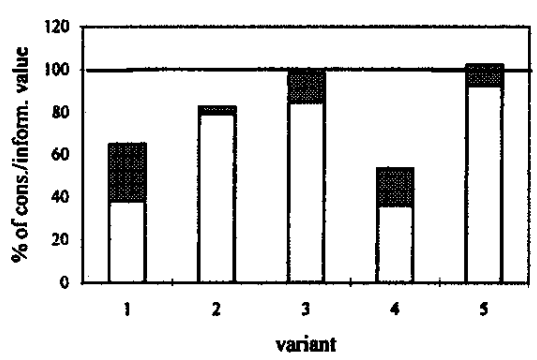

$\mathbf{P b}$

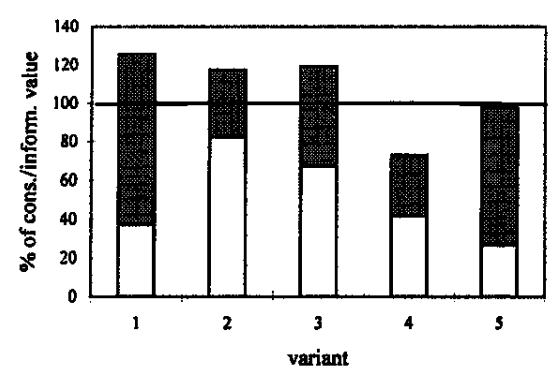

Cu

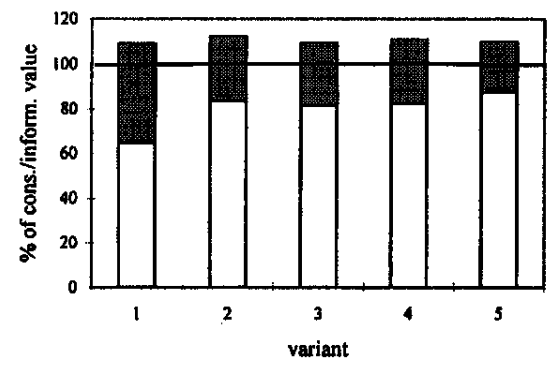

Mn

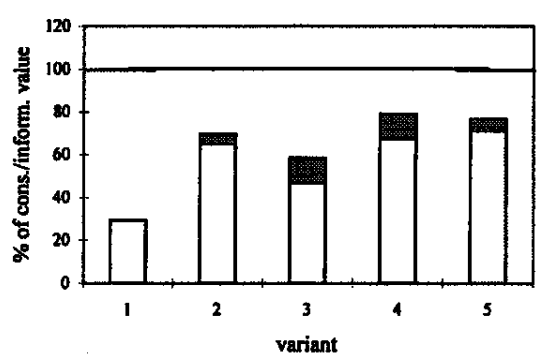

$\mathrm{Cr}$

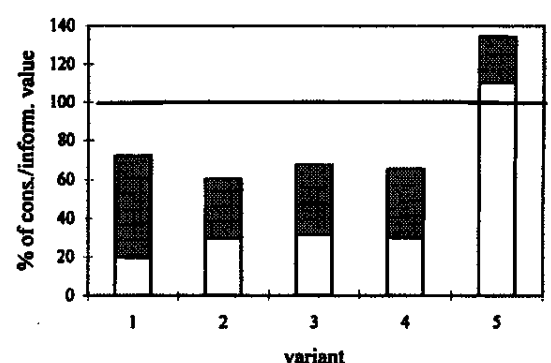

Zn

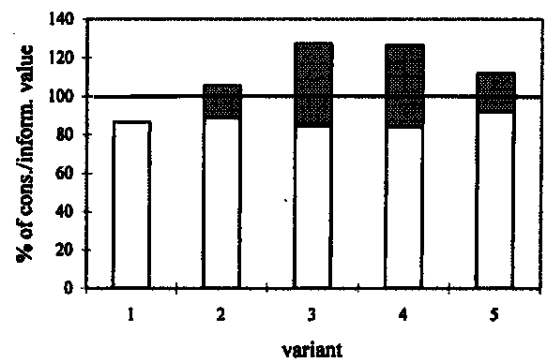

Fig. 4. Element contents in fraction released after ash leaching according to SOP-1 and after reaction of insoluble residue with a mixture of $\mathrm{HF}+\mathrm{HNO}_{3}$; experiment I. Arithmetic means, $n=3$. Mn and $\mathrm{Zn}$ in residue of variant 1 not determined. residue, solution, - consensus/information value.

relatively high content of $\mathrm{Cr}$ was identified in the solid residue $\left(13.3 \mathrm{mg} \mathrm{kg}^{-1}\right)$ and total content calculated as the sum of these two values exceeded significantly the information value for total content of chromium in NSC-21 (see above). Repeated decomposition of the NSC-21 sample after this variant suggested decreasing of the chromium level after sixfold dilution of the sample solution before AAS measurement with both acetylene-air and acetylene- $\mathrm{N}_{2} \mathrm{O}$ flames (to 52.3 and $49.5 \mathrm{mg} \mathrm{kg}^{-1}$, respectively). The last value of sum with the chromium content remaining in the solid residue corresponds to information value given above. On the contrary, the results of the repeated decomposition of NSC21 after variants $1-4$ increased by six-fold dilution of the sample solution so that the values vary in the range $21.1-$ $33.4 \mathrm{mg} \mathrm{kg} \mathrm{kg}^{-1}$ (flame acetylene-air) and 28.4 $39.1 \mathrm{mg} \mathrm{kg} \mathrm{g}^{-1}$ (flame acetylene- $\mathrm{N}_{2} \mathrm{O}$ ). As compared to the information value for partially released, plant available chromium content $\left(32.8 \mathrm{mg} \mathrm{kg}^{-1}\right)$, the last values seem to be relevant in this case. The interference of matrix elements (variants $1-4$ ) and the change of matrix compositions by addition of strong acid $\left(\mathrm{H}_{2} \mathrm{SO}_{4}\right)$ and/or high temperature during its evaporation is evident.

\section{Experiment /I}

The results of $\mathrm{Pb}, \mathrm{Cd}$ and $\mathrm{Cr}$ determinations are summarized in figure 5 and suggest conclusions similar to those of experiment I. Only after decomposition denoted as variant B (application of HF for decomposition of silicates) the results were in accordance with consensus and information values for NSC-21 sample, respectively. Wet ashing seems to be comparable with dry ashing techniques except lead (decreased value due to precipitation with $\mathrm{H}_{2} \mathrm{SO}_{4}$ ). The application of $\mathrm{HF}$ for decomposition of this type of material for determination of total contents of trace elements seems to be necessary in accordance with soil type [8] and lake sediment [9]. From the group of the wet ashing methods, aqua regia has been proposed as suitable digestion mixture for compost samples [10].

Results of the variant $\mathrm{C}$ (dissolution of the ash in a larger volume of $1.5 \% \mathrm{HNO}_{3}$ ) are similar as compared to the 


\section{Original articles}

$\mathbf{C d}$

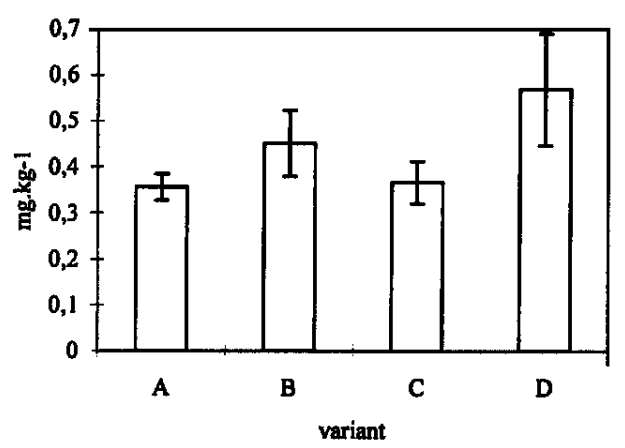

$\mathbf{P b}$

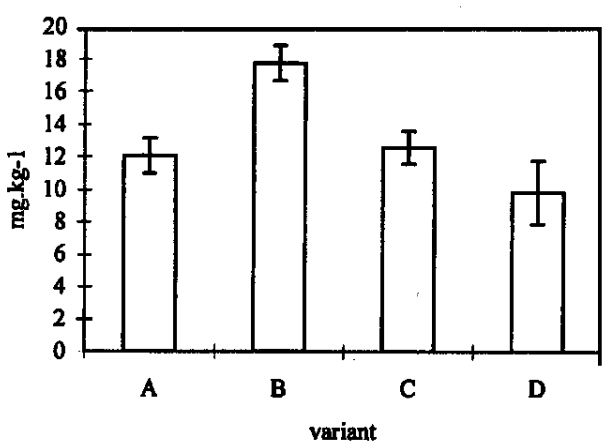

$\mathrm{Cr}$

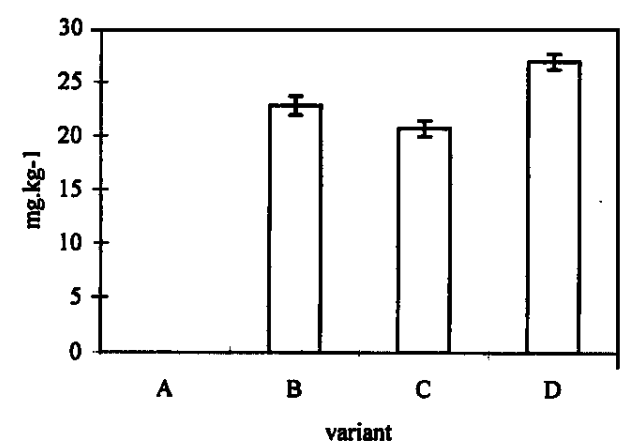

Fig. 5. Values for element contents in material NSC-21 $\left(\mathrm{mg} \mathrm{kg}^{-1}\right)$ obtained after ash leaching for individual variants of experiment II. Arithmetic means, $n=8$. Cr in variant A was not determined.

results of the variant $\mathrm{A}$ (dissolution of the ash in a smaller volume of more concentrated $\mathrm{HNO}_{3}$, see above). Larger final volume of the digest in combination with lower mass of sample led to better dissolution of elements of interest as described in [11] for selected macroelements. In addition, this procedure permits to overcome the possible interferences during AAS measurement.

\section{Discussion}

Surprising presence of $\mathrm{CaCO}_{3}$ calcite in the silicious fraction of the plant ash clearly demonstrates that the efficiency of the ash leaching is at least partly complicated by the physical state of the ash and the difficulty of the leaching medium (diluted acid) to penetrate entirely into its matrix. Two factors can be considered here: (1) The physical state of the ash depends to some extent on the details of the decomposition procedure; (2) mechanical disintegration of the ash prior to, or as a part of, the ash leaching step should further support the completeness of the analyte release from the residue. As we have demonstrated earlier, the removal of organic components of plant matrix when SOP-1 is used proceeds much faster than in the case of soft animal tissues (see e.g. Fig. 1 in Ref. [4]). Hence, we have modified the temperature-time regime for plant tissues so that we lowered the temperatures of the first three steps of charring from original 200,260 and $320{ }^{\circ} \mathrm{C}$ to 170,230 and $290{ }^{\circ} \mathrm{C}$. Ash disintegration is strongly improved when ultrasonic mixing is applied during ash leaching. Ultrasonic mixing has not been used by us when we worked with the PDS-84 and PDS-85 plant materials. Its introduction in the second half of 1985 resulted in powerful increase in the efficiency of the analyte release from the plant ash and of good agreement with certified values in plant reference materials even in instances when HF was not applied.

Another possibility how to support the efficiency of the ash leaching step without the necessity to completely dissolve the residue is the increase of concentration of the leaching acid. While we did not need to use this in case of plant materials, it showed to be necessary for us in the case of other types of materials, namely animal meals and industrial compost. From the table I published in our review [1] it is obvious that this arrangement is quite popular in the literature even in case of plant and animal tissues. Also the procedure used in the ARS Beltsville, USDA, favours higher concentration of the acids ("the dried plant material... was placed in a muffle furnace at $460{ }^{\circ} \mathrm{C}$ overnight $(16 \mathrm{~h})$; the ashes were then solubilized using conc. $\mathrm{HNO}_{3}(1 \mathrm{~mL})$, followed by $20 \% \mathrm{HCl}(5 \mathrm{~mL})$ " [12]). Increase of leaching acid concentration is sometimes further supported by elevating the temperature. According to our experience, in the case of plant materials ultrasonic mixing improves the efficiency of the ash leaching and neither higher acid concentration nor higher temperature are in most instances necessary.

Industrial compost and some of its components belong to the most difficult materials, obviously in connection with the high representation of mineral constituents, part of which only is formed by silicates. High concentrations of leaching acids seem to be a necessity here. Thus, in the case of compost Anderson [13] found by treatment of insoluble residues after $\mathrm{HNO}_{3}$ extraction $\left(\mathrm{H}_{2} \mathrm{SO}_{4}+\right.$ dry ashing $)$ the following increase of element contents: $\mathrm{Cd} 28 \%, \mathrm{Cr} 25 \%, \mathrm{Mn} 22 \%$, $\mathrm{Ni} 20 \%$, Co $9 \%$, Zn 6\%, while the concentrations of $\mathrm{Cu}$ and $\mathrm{Pb}$ decreased by 22 and $13 \%$, respectively. There are different problems with different elements but chromium remains the most problematic one. Its determination is difficult even in biological material Brewer's Yeast and complete dissolution of the residue in HF is necessary to achieve accurate analytical result.

\section{Conclusion}

Classical dry ashing can be used with advantage in analyses of a broad range of materials of biological origin. Risk of retention of part of the analytes in an insoluble residue can be strongly suppressed by adequate modifications of the steps of charring and, in particular, ash leaching. Ultrasonic mixing significantly increases the efficiency of the latter 
step, which can be further supported by increased concentration of the leaching acid. Materials which besides organic components contain as well large amounts of mineral constituents require the most aggressive procedure, the safest being complete dissolution of the residue in leaching medium.

With dry ashing remains, of course, the problem of the determination of volatile elements as arsenic or selenium. For this purpose, the application of a wet digestion procedure is usually preferred. However, there are ways how to suppress or avoid losses of easily volatile elements (even including mercury) in classical dry ashing. This problem will be discussed in detail in part III of this series.

\section{Acknowledgement}

Part of this study (alfalfa leaves) has been sponsored by the PÚDIS Prague (grant No. 82-95-65). INAA analyses were kindly performed by I. Obrusník and J. Kucera from the Institute of Nuclear Research, Rez near Prague, chemical and X-ray structural analysis of the ash and its silicious residue by R. Pribil and A. Zdimera, Faculty of Science, Charles University of Prague. The technical assistance of Z. Svatos with part of the AAS measurements is also acknowledged.

\section{Appendix}

Standard Operation Procedure No. 2 of the Trace Element Laboratory, Department of Chemistry, Czech University of Agriculture in Prague.

\section{Dry ashing of higher plant tissues}

1. Designed for: a variety of higher plant leaves, stalks, roots, seeds and fruits. For some materials (cocos palm leaves, oil palm leaves, barley straw, cabbage roots) the remaining silicious residue can tightly absorb significant fraction of the elements to be determined. In such cases, the ash has to be dissolved in $\mathrm{ANO}_{3}+\mathrm{HF}$ mixture to remove all silicon from the sample matrix.

2. Weight of dry sample: 1 to $2 \mathrm{~g}$, also less than $1 \mathrm{~g}$ (but not less than $100 \mathrm{mg}$ dry material).

3. Charring: dry sample of known weight, placed in a reaction vessel $(50 \mathrm{~mL}$ quartz or borosilicate glass beaker $38 \mathrm{~mm}$ internal diameter, $60 \mathrm{~mm}$ height) covered with watch glass, is inserted onto a cold hot plate located in fume hood with switched-on exhaust. About 20\% of the beakers are reserved for monitoring background contribution (blind samples), and an additional beaker for RM (certified or internal reference material). Temperature of $170{ }^{\circ} \mathrm{C}$ is first selected. After $1 \mathrm{~h}$, it is changed to $230^{\circ} \mathrm{C}$, after another hour to $290{ }^{\circ} \mathrm{C}$ and after another hour to $380{ }^{\circ} \mathrm{C}$. This temperature is maintained for $1 \mathrm{~h}$, hot plate is switched off, watch glasses are removed and beakers are transferred to bottom of fume hood.

4. Ashing: beakers (without watch glasses) are transferred to cold muffle furnace. Furnace is then closed and the temperature regulator is switched to $350{ }^{\circ} \mathrm{C}$. After $30 \mathrm{~min}$ the regulator is switched to $400{ }^{\circ} \mathrm{C}$, after another $30 \mathrm{~min}$ to $450{ }^{\circ} \mathrm{C}$, and after another $30 \mathrm{~min}$ to $500^{\circ} \mathrm{C}$. Then it is left in this position for approx. $16 \mathrm{~h}$ (overnight). Next morning furnace is switched off, after $30 \mathrm{~min}$ it is opened, and beakers are transferred to laboratory counter.

5. Addition of ashing aid: after cooling down to room temperature, exactly $1 \mathrm{~mL} \mathrm{HNO}_{3}(67 \%)$ for semiconductors or suprapure is added to each beaker. Beakers (without watch glasses) are transferred to the cold "hot plate". Temperature regulator is then turned on $140{ }^{\circ} \mathrm{C}$, and beakers are left on "hot plate" just until all excess $\mathrm{HNO}_{3}$ and water have evaporated.

6. Repeated ashing with ashing aid: beakers (without watch glasses) are again returned to muffle furnace. Temperature regulator is kept at $500{ }^{\circ} \mathrm{C}$, and furnace is switched on. After $1 \mathrm{~h}$, furnace is switched off, after additional $30 \mathrm{~min}$ it is opened, and beakers are transferred to the laboratory counter.

7. Ash leaching: about $5 \mathrm{~mL}$ diluted $\mathrm{HNO}_{3}$ (1.5\%) and $1 \mathrm{~mL} \mathrm{HNO}_{3}(67 \%)$ is put into each beaker and the beakers are left stand for one hour at room temperature. Beakers (without watch glasses) are then transferred into ultrasonic bath combined with dissolution device (according to ZN No. 6/88, Univ. of Agr. Prague). All beakers are covered with one plexi glass lid, and ultrasound generator is switched on. After $5 \mathrm{~min}$, generator is switched off, beakers are transferred onto laboratory counter and, after drying off outer walls and bottoms of beakers, the content of each beaker is quantitatively transferred into a calibrated test tube (10 or $20 \mathrm{~mL})$. For washing out beakers, and for filling test tubes up to the required volume ( 10 to $20 \mathrm{~mL}$ ), the diluted $(1.5 \%) \mathrm{HNO}_{3}$ is again used. Calibrated test tubes are then covered with parafilm and stored at least $24 \mathrm{~h}$ at room temperature in dust-free space.

\section{References}

1. Mader, P.; Száková, J.; Curdová, E. Talanta 1996, 43, 521.

2. Hoenig, M.; Vanderstappen, R. Analusis 1978, 6, 312

3. Hoenig, M.; Kersabiec, A.-M. Spectrochim. Acta Part B 1996, 51, 1297.

4. Mader, P.; Haber, V.; Zelinka, J. Analusis 1997, 25, 175.

5. Cibulka, J.; Slavík, L.; Mader, P.; Miholová, D.; Reznícková, J. Zivocisná vyroba 1990, 35, 185.

6. Bock, R.; A Handbook of Decomposition Methods in Analytical Chemistry, International Textbook Company, London, 1979.

7. Mader, P.; Száková, J.; Kucera, J. Biol. Trace Elem. Res. 1994, 43-45, 633.

8. Holynska, J.; Jasion, J.; Lankosz, M.; Markowicz, A.; Baran, W. Fresenius Z. Anal. Chem. 1988, 332, 250.

9. Cheam, V.; Aspila, K. I.; Chau, A. S. Y. Sci. Total Environ. 1989, 87/88, 517.

10. Lustenhouwer, J. W. A.; Hin, J. A.; Maessen, F. J. M. J.; Den Boef, G. Intern. J. Environ. Anal. Chem. 1990, 39, 209.

11. Rosopulo, A.; Hahn, M.; Stärk, H.; Riedler, J. Landw. Forsch. 1975, 32, 199.

12. Chaney, R. L. Procedure for plant sample preparation for analysis by dry ashing. Analytical methods protocol, unpublished internal report, USDA, ARS Beltsville, 1991.

13. Anderson, A. Swedish J. Agric. Res. 1976, 6, 145. 